\title{
ISOLASI DAN IDENTIFIKASI CEMARAN BAKTERI Salmonella sp. PADA DAGING AYAM DAN IKAN MENTAH
}

\section{ISOLATION AND IDENTIFICATION OF Salmonella sp. CONTAMINATION FROM CHICKEN AND FISH RAW MEAT}

\author{
Hasnaul Maritsa"1, Fitratul Aini' ${ }^{2}$, Desri Santi Nurhakim³, Greace Meisinta Sihombing ${ }^{4}$, \\ Ardiansyah Saputra ${ }^{5}$ \\ 1,2,3,4,5 Prodi Biologi, Fakultas Sains dan Teknologi, Universitas Jambi \\ Email : *1hasnaul.maritsa123@gmail.com, ${ }^{2}$ fitratulaini47@gmail.com, ${ }^{3}$ desrisanti96@yahoo.com, \\ ${ }^{4}$ greace.meisita@gmail.com. ${ }^{5}$ pardiansyah74@yahoo.com
}

\begin{abstract}
Food is a basic need that must be free from microorganisms contamination Salmonella sp. is a gram-negative bacteria that often contaminates food, especially meat, and causes Salmonellosis disease. This study aims to isolate and identify Salmonella sp. which allegedly contaminating the sample of chicken meat and raw fish. Samples from traditional market around Jambi University. The tests were conducted at the Laboratory of Biotechnology and Engineering, Faculty of Science and Technology, Jambi University. Isolation was performed by dilution method on SSA medium (Salmonella Shigella Agar), isolates were characterized by macroscopic-microscopic morphology, and biochemical test. The results showed that raw chicken meat was positively contaminated with Salmonella sp., while fish meat was not. Gram-negative bacillus isolate character is yields $\mathrm{H}_{2} \mathrm{~S}$ black deposits and is capable of fermenting glucose, lactose and sucrose.
\end{abstract}

Keyword : Fishmeat, Chicken Raw Meat, Salmonella sp., Salmonellosis

\section{PENDAHULUAN}

Makanan merupakan salah satu kebutuhan pokok bagi kehidupan manusia guna memenuhi kebutuhan energi untuk melakukan aktivitas sehari-hari. Selain itu makanan juga berfungsi untuk memenuhi kebutuhan nutrisi dan fungsi fisiologis tubuh lain nya. Agar makanan dapat berfungsi sebagaimana mestinya maka kualitas makanan harus terus diperhatikan, melalui ketersediaan zat-zat gizi yang terkandung didalamnya.

Kualitas makanan yang baik dapat dilihat dari kondisinya yang harus dalam keadaan bersih dan terbebas dari cemaran mikroorganisme patogen yang beresiko menyebabkan penyakit. Penyakit ini dikenal dengan istilah Food-borne disease (Mulia, 2005).
Salah satu mikroorganisme yang kerap mengkontaminasi bahan makanan adalah Salmonella sp. Kadar Salmonela sp. pada makanan menurut Badan Pengawasan Obat dan Makanan (BPOM) Republik Indonesia, yaitu negatif per $25 \mathrm{mg}$ makanan (Tamrin, et al. 2009). Bahan makanan yang sering terdapat kontaminasi bakteri Salmonella sp. adalah daging, diantaranya daging ayam dan daging ikan. Daging ayam dan ikan memiliki kadar air dan protein yang tinggi sehingga dapat dengan mudah terkontaminasi oleh bakteri yang nantinya menyebabkan penyakit (Brooks, 2005).

Penyakit yang disebabkan oleh bakteri Salmonella sp. disebut dengan Salmonellosis. Salmonellosis merupakan gangguan yang terjadi pada sistem pencernaan. Gejala utama penyakit ini adalah diare. Gejala bisa 
saja ringan, seperti mencret 2-3 kali sehari. Namun, gejala diare parah mampu menyebabkan mencret setiap jangka waktu 10 atau 15 menit. Gejala lainnya adalah feses dapat disertai dengan darah, kram perut, muntah, demam dan sakit kepala (Srigede, 2015).

\section{METODOLOGI PENELITIAN}

Penelitian ini dilakukan di Laboratorium Bioteknologi dan Rekayasa, Universitas Jambi. Pengambilan sampel daging ikan di warung perumahan mendalo asri dan daging ayam segar di pasar tradisional sekitar Universitas Jambi.

Sampel diisolasi dengan teknik pengenceran $10^{-5}$ dan ditumbuhkan pada media selektif SalmonellaShigella Agar (SSA). Inkubasi dilakukan pada suhu $37^{\circ} \mathrm{C}$ hingga diperoleh kultur murni. Selanjutnya dilakukan karakterisasi secara makroskopis dan mikroskopis serta uji biokimiawi meliputi pewarnaan Gram, uji TSIA, dan SIM terhadap isolat yang menunjukkan positif Salmonella sp.

\section{HASIL DAN PEMBAHASAN}

Berdasarkan isolasi dari daging ayam dan daging ikan mentah pada media SSA, menunjukkan bahwa sampel yang positif mengandung Salmonella sp. adalah daging ayam. Sedangkan untuk sampel ikan negatif mengandung Salmonella sp. Media SSA mampu menghambat pertumbuhan bakteri gram positif sehingga medium ini bersifat selektif untuk bakteri gram negatif khususnya Salmonella-Shigella yang tumbuh dan berkembang biak berdasarkan komposisinya.

Pertumbuhan Salmonella sp. pada media SSA ditandai dengan terbentuknya koloni berwarna kehitaman karena Salmonella sp. dapat menghasilkan $\mathrm{H}_{2}$ S. Media SSA mengandung sodium thiosulphate yang dirombak oleh mikroorganisme enterik tertentu menjadi sulfit dan gas $\mathrm{H}_{2} \mathrm{~S}$ menggunakan enzim reduktif tiosulfat reduktase. Produksi gas $\mathrm{H}_{2} \mathrm{~S}$ dideteksi sebagai endapan hitam ferrous sulfida yang tidak larut, terbentuk pada reaksi $\mathrm{H}_{2} \mathrm{~S}$ dengan ion ferric atau ferric citrate, yang ditunjukkan di tengah koloni (Budiarso dan Maria, 2009).

Daging ayam yang diduga positif mengandung Salmonella sp., memperlihatkan warna pada media SSA berubah dari merah menjadi kuning, akibat adanya kemampuan bakteri Salmonella sp. dalam memfermentasi laktosa (Gambar 1)

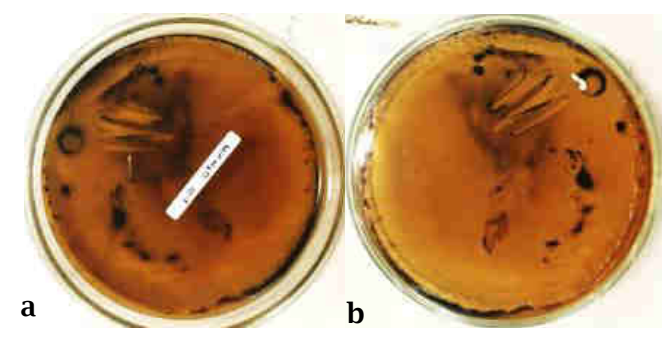

Gambar 1. Biakan Salmonella sp.

Keterangan :

(a) perubahan warna media SSA dari merah menjadi kuning,

(b) goresan pada media SSA

Pengamatan secara mikroskopis menunjukkan isolat basil berwarna merah muda dan bersifat gram negatif. Hal ini sesuai dengan White dkk, (2000), yang menyatakan bahwa Salmonella sp. merupakan bakteri gram negatif (Gambar 2).

Pengujian secara biokimiawi seperti TSIA menunjukkan bahwa isolat memiliki kemampuan dalam memfermentasi 3 macam gula yaitu glukosa, laktosa dan sukrosa. Hasil positif lainnya adalah pembentukan gas dari fermentasi $\mathrm{H}_{2} \mathrm{~S}$ dan $\mathrm{CO}_{2}$ dapat dilihat dari pecah dan terangkatnya media agar pada tabung. (Gambar 3). 


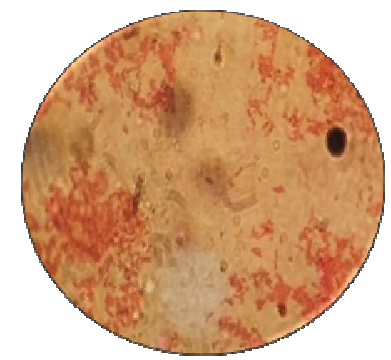

Gambar 2. Pengamatan mikroskopis Salmonella sp. (Perbesaran.1000X).

Keterangan :

Bentuk bakteri basil dan berwarna merah muda

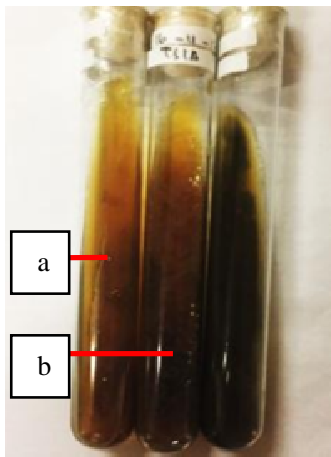

Gambar 3. Hasil Uji TSIA

Keterangan :

(a) hasil (+) perubahan warna media menjadi kuning kemampuan isolat memfermentasi 3 glukosa,

(b) endapan hitam $\mathrm{H}_{2} \mathrm{~S}$

Pembentukan $\mathrm{H}_{2} \mathrm{~S}$ positif ditandai dengan adanya endapan berwarna hitam, endapan ini terbentuk karena bakteri mampu mendesulfurasi asam amino dan methion yang akan menghasilkan $\mathrm{H}_{2} \mathrm{~S} . \mathrm{H}_{2} \mathrm{~S}$ akan bereaksi dengan $\mathrm{Fe}^{+}$yang terdapat pada media dan menghasilkan endapan hitam.

Dari hasil pengamatan pada tabung terlihat adanya endapan hitam.

\section{DAFTAR PUSTAKA}

Amiruddin, R., R. Darniati, Ismail. 2017. Isolasi dan Identifikasi Salmonella sp. pada Ayam Bakar di Rumah Makan Kecamatan Syiah Kuala Kota Banda Aceh. Jimvet. Vol. 1. No. 3. Hal: 265-274.
Hal ini sesuai dengan penelitian Haryani, dkk (2012), bahwa pada reaksi spesifik untuk Salmonella sp. adalah adanya endapan merah-hitam yang disebabkan adanya proses oksidasi asam oleh udara pada bagian agar miring dan pemecahan protein.

Pada uji SIM (Sulfid-Indool Motility), menunjukkan terbentuknya pola adanya pergerakan bakteri di permukaan media yang berwarna putih seperti kapas dan terdapat gas $\mathrm{H}_{2} \mathrm{~S}$ (Gambar 4), hal ini menandakan isolat motil. Salmonella merupakan bakteri bakteri gram negatif yang tergolong motil.

Gambar 4. Hasil uji SIM

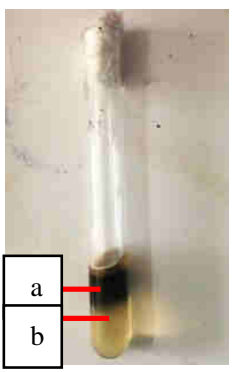

Keterangan :

(a) pola sebaran pergerakan bakteri berwarna putih seperti kapas,

(b) endapan $\mathrm{H}_{2} \mathrm{~S}$

\section{KESIMPULAN}

Berdasarkan hasil penelitian maka dapat disimpulkan dari kedua sampel, daging ikan mentah tidak terkontaminasi oleh cemaran Salmonella sp., sedangkan daging ayam positif terkontaminasi cemaran bakteri gram negatif Salmonella sp.

Aulia, R., Tri H., Yusma Y. 2015. Isolasi Identifikasi dan Enumerasi Bakteri Salmonella spp. pada Hasil Perikanan Serta Resistensinya terhadap Antibiotik. Bioma. Vol II. No. 1. 
Budiarso, Tri Y., Maria J. X. B. 2009. Deteksi Cemaran Salmonella pada Daging Ayam yang Dijual di Pasar Tradisional di Wilayah Kota Yogyakarta. Prosiding Seminar Nasional Penelitian Pendidikan dan Penerapan MIPA. Yogyakarta : UNY.

Brooks, G. F., Butel, J. S. Morse, S. A. 2005. Mikrobiologi Kedokteran Ed 1. Jakarta : Salemba Medika.

Haryani Y, Chainufillah, Rustiana. 2012. Fermentasi Karbohidrat oleh Isolat Salmonella spp. dari Jajanan Pinggir Jalan. Jind Che Acta. Vol. 3 (1).

Kusuma A. S., Masdiana C. P., Dyah K. 2012. Isolasi dan Karakterisasi Salmonella spp. di Lingkungan Rumah Potong Ayam di Kota Malang. Jurnal Sehat. Vol. 1. No. 2. Hal: 1-8.

Mulia, Ricky, M. 2005. Kesehatan Lingkungan. Edisi Pertama. Jakarta: Graha Ilmu.

Suwito, W. 2010. Monitoring Salmonella spp. dan Escherichia coli dalam Pakan Ternak.
Buletin Peternakan. Vol. 34. No. 3. Hal: 165-168.

Srigede, G.L. 2015. Studi Identifikasi Bakteri (Salmonella sp.) pada Jajanan Cilok yang Dijual di Lingkungan SD Kelurahan Kekalik Kecamatan Sekarbela Kota Mataram. Media Bina Ilmiah. Vol 9(7): 28-32.

Thamrin, Husnina. 2009. Peraturan Kepala Badan Obat dan Makanan tentang Penetapan Batas Maksimum Cemaran Mikroba dan Kimia dalam Makanan. Jakarta: BPOM.

White, D. G., S. Zhao, R. Sudler, S. Ayers, S. Friedman, S. Chen, P. F. McDermott, S. McDermott, D. D. Wagner, J. Meng. 2001. Salmonella from Retail Ground Meats. Engl. J. Med. Vol. 345: 1147-1154.

Yuswananda, P.N. 2015. Identifikasi Bakteri Salmonella sp. pada Makanan Jajanan di Masjid Fathullah Ciputat Tahun 2015. Skripsi. Jakarta : UIN. 